\title{
3. War reporting, international humanitarian law and the legacy of Balibo
}

\section{COMMISNIARY}

Organisations like the International News Safety Institute (INSI), formed in 2001 and based in Brussels, have created an impressive global network to help news workers facing danger on assignment; as well, big networks such as the $\mathrm{BBC}, \mathrm{CNN}$ and the $\mathrm{ABC}$ have adopted measures including battlefield security courses, protective gear, first-aid training, and carefullyrehearsed exit strategies. Despite all this, reporters are still being targeted, and too many governments are still ignoring, and even giving support to, the killing of journalists.

Keywords: armed conflict, conflict reporting, disaster reporting, Geneva Conventions, humanitarian law, war reporting

TONY MANIATY

University of Technology, Sydney

RMED CONFLICT is endemic in the modern world. There are ma-
jor battlefields such as Iraq and Afghanistan, plus as many as 20
lesser-known but still extremely violent wars - or, as a BBC correspondent once put it, 'small-scale wars of large-scale awfulness'. Whatever the scale of fighting and suffering, the media is usually there: gathering information and evidence, and putting themselves at high risk - often risk of death. Frontline reporting is an extremely dangerous activity: countless journalists died in both World Wars of the 20th century and somewhere between 40 and 70 (the exact number is contested) lost their lives in the Vietnam War. Over the past decade, more than 1000 journalists and news support staff, including translators, fixers, and drivers, have died while covering wars, natural disasters, crime, unrest and other dangerous stories.

Organisations like the International News Safety Institute (INSI), formed 


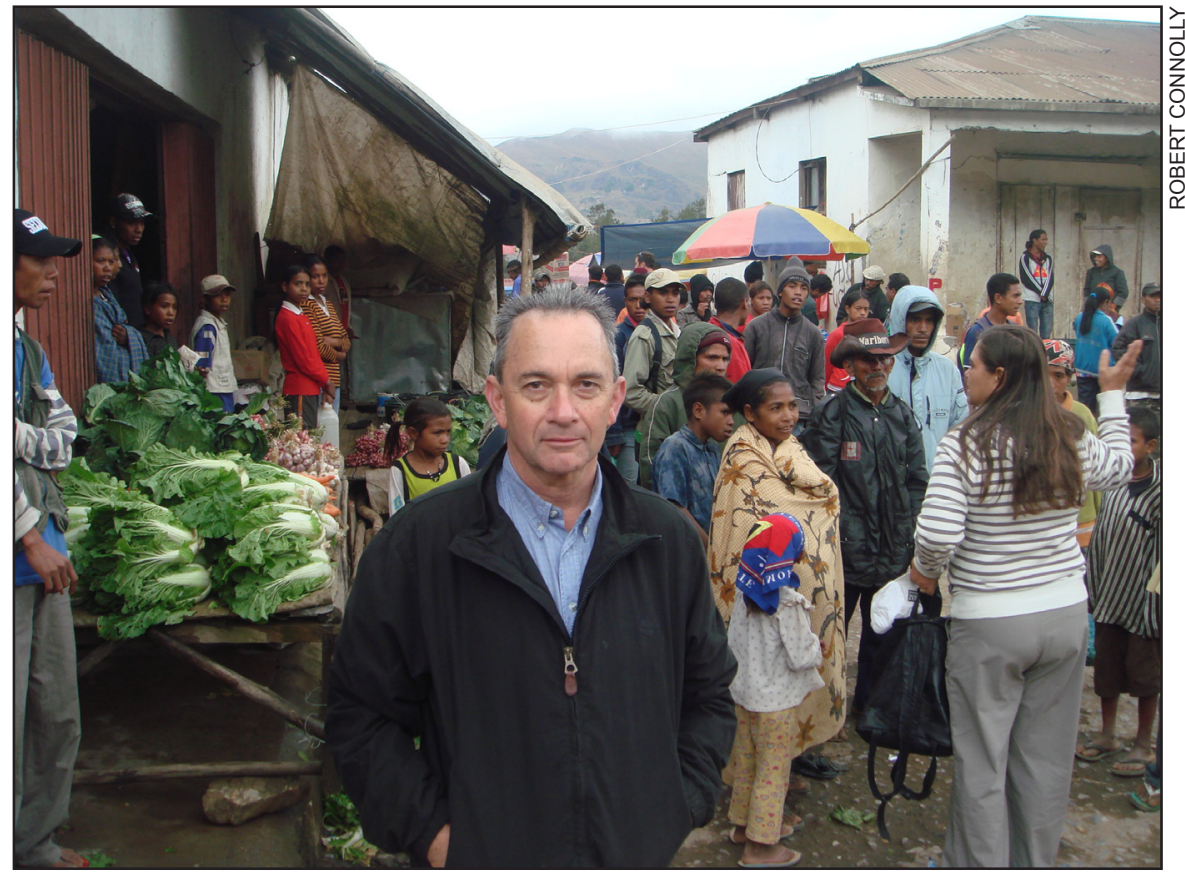

Shooting Balibo author Tony Maniaty on location in East Timor for the film Balibo in 2008.

in 2001 and based in Brussels, have created an impressive global network to help news workers facing danger on assignment; as well, big networks such as the $\mathrm{BBC}, \mathrm{CNN}$ and the $\mathrm{ABC}$ have adopted measures including battlefield security courses, protective gear, first-aid training, and carefully-rehearsed exit strategies. Despite all this, reporters are still being targeted, and too many governments are still ignoring, and even giving support to, the killing of journalists. International Humanitarian Law (IHL) sits at the very core of this risk-laden enterprise, as it has since the Geneva Conventions of 1949 consolidated the international law of armed conflict into key legal documents - based on principles established by Henri Dunant, founder of the International Committee of Red Cross. The Geneva Conventions are the bedrock of IHL. But what, if anything, does IHL say about the protection of journalists covering armed conflicts? The First Additional Protocol to the Geneva Conventions of 1949, Article 79 says:

1. Journalists engaged in dangerous professional missions in areas of armed conflict shall be considered as civilians (...). 
2. They shall be protected as such under the Conventions and this Protocol provided that they take no action adversely affecting their status as civilians $(\ldots)$

In the ICRC Study on Customary Rules of IHL (2005), Rule 34 in Chapter 10 further states that:

Civilian journalists engaged in professional missions in areas of armed conflict must be respected and protected as long as they are not taking a direct part in hostilities. (...) State practice establishes this rule as a norm of customary international law applicable in both international and non-international armed conflicts.

Given the above, the following then applies to journalists:

In all armed conflicts, IHL explicitly prohibits the following acts committed against persons not or no longer taking an active part in hostilities: any violence to life and person, in particular murder of all kinds, mutilation, cruel treatment and torture; the taking of hostages; outrages upon personal dignity, in particular, humiliating and degrading treatment; the passing of sentences and the carrying out of executions without previous judgment pronounced by a regularly constituted court affording all the judicial guarantees which are recognised as indispensable by civilised peoples.

In other words, journalists covering war are to be treated as civilians and given the protection afforded to civilians. Yet this is not always the case. Modern warfare is the equivalent of chaos theory in action, which makes reporting it harder and more dangerous than ever. There are numerous reasons why this is so. Ballistics now run at higher speeds, with more power, and do greater damage to the human body. Armies and guerrilla groups have upped armaments: rocket-propelled grenades are standard issue. War zones are less likely to be in open fields and more in crowded towns, buildings and backstreets; shrapnel bounces off walls and into bodies, and explosions have more devastating impacts. IEDs - improvised explosive devices - are pervasive, as are suicide bombers. There is no clear frontline; most armies now fight in a maze where enemies are hard to detect and even harder to dislodge. Journalists covering war in the 21 th century need the same 
sort of protective gear as soldiers, and often end up looking not unlike soldiers, and holding cameras that look like weapons - with disastrous results. The very nature of conflicts has changed dramatically. Most fighting now is internal, within states rather than between states; between tribes and clans and gangs often broken into differing factions based on politics, ethnicity, criminality. Less conflict is fought by regular armies and more by armed groups comprising mixtures of soldiers, police and criminals, rebels and insurgents. All of which is hardly a recipe for the civilised conduct of war, or for the unambiguous application of international legal standards.

Even if correspondents survive such horrors, they are still highly vulnerable. No longer regarded as neutral observers, war reporters are now seen as active players in warfare - and, in many ways, they are. Live TV coverage screened worldwide has a huge influence on military and geo-political strategy. Conversely, silencing journalists is part of the battle plan too, whether through censorship on one side or suicide bombing on the other-taking out a television crew is seen as a greater insurgent propaganda victory than killing, say, a US Marine, if only because of the media attention it generates. If you can kidnap a correspondent from a major network, it's possible to raise a million dollars in ransom - to buy more weapons, to kill more enemies. This, not unnaturally, has the effect of scaring off many journalists. It would seem improbable that anyone aware of how Wall Street Journal reporter Daniel Pearl was beheaded on video at the hands of Islamic extremists would want to follow in his footsteps. Yet they do, prompting a new dilemma. Young, inexperienced freelancers are now working around the TV network protection systems by simply buying a laptop and handycam, a cheap air ticket to places such as Kabul, and heading to the frontline, hoping for spectacular footage to sell to networks. Few know anything about international humanitarian law; even if they did, few would think it had much to do with getting into a war zone, getting great pictures and stories and getting out alive. In that sense, they are placing themselves in the situation not unlike that which the reporters leading the Australian TV crews in East Timor - myself from the ABC, Greg Shackleton from Channel Seven, Mal Rennie from Channel Nine-faced back in 1975. None of us had been in a war before. We were ill-equipped and ill-prepared for the dark and lethal events that followed. Flak jackets for journalists were unheard of in those days, so we wore jeans and shorts and T-shirts in the tropical heat; we took no serious medical supplies, no emergency food supplies. 
We had no radios, no means of communicating with the outside world, and had no evacuation plans except to stick close to Fretilin's soldiers and hope somehow they would save our lives if things went haywire.

All of us made mistakes at Balibo. Some of those errors may well have contributed to the terrible outcome in which five newsmen died-executed, according to the New South Wales Coroner's report of 2007 into the death of cameraman Brian Peters, by Indonesian forces. That we were all so rigidly attached to the Fretilin armed forces was not in itself a mistake (moving through hostile territory on the border with Indonesia, there was no option for our safety) but it could hardly have helped to promote an image of independent journalism. This was exacerbated by errors of judgment. On one occasion, Greg Shackleton conveyed military information for Fretilin, a point noted in the Coroner's report. 'At Maliana', declared Shackleton in his report to camera, 'we conveyed a message that reinforcements be sent from Maliana to Balibo. We asked for 15 men as we were told, in two cars, but they say that all they can spare is five men to help the ten still in Balibo'. Under the Geneva conventions, Shackleton should have rejected any request to convey for Fretilin what was clearly information of a military nature, which amounted to 'participatory behaviour' - the job of reporters being to observe, not to engage with the surrounding conflict. Yet the situation was risky and Fretilin were essentially our protectors. We do not know if Shackleton was even aware that such action contravened the Geneva accords; notions of humanitarian law were unknown to most journalists. This was 1975 - the ground rules for television war coverage were still being drawn up, and we were among the pioneers.

All of us also carried an instinctive feeling that we would not be deliberately targeted simply for being journalists; up to that point, in Vietnam, virtually all television journalists killed on the frontline had been caught in crossfire, in an ambush, in a hail of shrapnel, or even under friendly fire. To that we should add another element of frontline naivety: that something about 'being Australians' would protect us. Greg Shackleton famously painted the word AUSTRALIA on a house wall in Balibo. That image has become synonymous with the tragedy, yet there is, after all these years, a terrible innocence conveyed in that action. Shackleton in his television report says they have painted the sign 'hoping it may afford us some protection'. It is hard to imagine that it might offer substantial protection, and might well do precisely the opposite, drawing attention to their presence. Yet perhaps we all felt that 
same spirit: that, as easygoing Australians (or Australian-based Westerners), we were somehow not linked to the dangerous flux of events that swirled through the region; that as Australians, we were all likeable people with no malicious intent; that as Australians, we should not be judged on foreign shores by any standards but our own. In 1975, Indonesian commandos clutching machine guns and determined to wipe out Fretilin, carried no such subtleties or illusions in their heads. It's hardly a mystery why the Indonesians should seek to eliminate witnesses to their illegal incursion into a foreign territory - invading armies do that sort of thing with shameless regularity.

If we can imagine that we were all more experienced, and far wiser about IHL and other international conventions of war than we were, what notions might we have taken into battle, into Timor with us? For a start, the idea that war is not a situation of open slather; that not everything is permitted even within the dark parameters of that thing called war. That in fact, as journalists, we were subjected to various codes that we needed to follow, and that combatants on both sides had to follow, to ensure our safety and survival. War, of course, is war, but war is not without civilised limits of behavior, and IHL looks at 'the rules of the game' of war-beyond which, war produces war crimes.

All this is now globally recognised. The Geneva Conventions, the basis of IHL, are ratified by every state on earth. They are binding on all states and apply worldwide, whatever the conflict, whatever the ideology or passions driving the conflict. They make no distinctions or judgments about which side is right or wrong. (This is especially important for correspondents, who usually find themselves reporting the conflict not from both sides, but from one side or the other.) IHL likewise is not involved with journalists' freedom of action or freedom of speech; it does not grant rights to enter a war zone per se-the reporter has to negotiate that on the ground with the consenting authorities, whoever they might be. But IHL does set basic rules for the legal protection of journalists operating in conflict zones, and these are a solid base on which war reporting can be conducted, and judgments made. It also lets them know what is legally permissible in their role as media workers, and also legally what combatants can do about the presence of journalists and what they cannot. Invoking the rule of law and the possibility of war crimes prosecutions may not seem much of a weapon against schoolboy soldiers clutching AK-47s, 
but among their senior officers it can signal that the forces they control are under international scrutiny. That alone can be a powerful deterrent. For journalists, understanding IHL is not just a matter of survival, it's also about reporting accuracy. Knowing the rules of the game allows reporters to draw attention in stories to violations of IHL. Journalists are witnesses to history, and history tells some very cruel tales. As a witness to violations of human rights, the war correspondent is in a position to tell the world more quickly than most what is happening, and to document such violations in order to halt them and/or to bring the perpetrators to justice. Lindsey Hilsum, who covered the horrors of Rwanda for British television, says that had she realised that she wasn't reporting anarchy but genocide, she would have reported it quite differently. 'In that first terrible week,' she said, 'I could have explained that governments had an obligation to stop it' (cited by Pratt, 2009).

One key principle of the Geneva Conventions is the notion of proportionality, that the use of force is not unlimited. Prohibitions exist against methods that cause unnecessary suffering to persons, and/or long-term and severe damage to the natural environment. A reasonable balance must be struck between the effects of legitimate military destruction and undesirable collateral effects. Under IHL, the use of weapons such as dumdum bullets, chemical and biological weapons and blinding laser weapons is prohibited. Knowing all this, and reporting IHL abuses, makes for good journalism

The notion that the war correspondents of today are essentially the same as their colleagues of 50 years ago but with laptops, satellite dishes and better cameras is a fallacy. There are notable exceptions - people who operate with rigorous independence from all authority and control - but these are rare; the emergence of a media-military complex, in which journalists are heavily integrated into the fighting machine and into the coverage of one perspective only of war, has fundamentally changed the nature of the business.

To a very large degree it also clouds the whole question of IHL as applied to war reporting. The closer the media gets to the military, the harder it becomes - whatever IHL might say in theory - to uphold in practice their status as civilians, to protect them from combatants locked in life-and-death struggles. This may lead many to question whether IHL has any real meaning, or power, in the contemporary war zone? Isn't the battlefield essentially hell on earth, a jungle where no civilised behaviour exists and no conventions will save us? 
The issue is not whether IHL offers adequate protection to media workers. On paper it does. What's lacking is vigorous implementation of IHL and the systematic investigation, prosecution and sanction of violations. It is true that those who are most likely to break the rules-undisciplined, ad hoc armed groups with weak leadership and often extreme ideologies - are those least likely to undertake training on IHL issues and the rights of civilians populations. But we have also seen the armies of advanced nations abuse their power, and impose acts of violence on the media. Governments often protect allied governments in defending these indefensible acts. Because so much of modern war has become lawless, and is increasingly so, we need more than ever to vigorously apply laws that cover not only those who are its backroom perpetrators, those who fight it and those who are its civilian victims, but also those who cover it.

If you travel to East Timor today and make your way to Balibo, you'll come across the building commonly known as the Australia House, where the Balibo Five slept and where Greg Shackleton painted the word AUSTRALIA on the outside wall. Inside, it's a community centre-photos of the Balibo Five hang from the wall, and there's a visitor's book. Most of the tributes are heartfelt: 'The price of freedom is high' and 'The ultimate price, not to be forgotten', but at the bottom of one page appears a bolt of pure aggression: 'They deserved what they got - no heroes here', and under it, 'I agree'.

It's a harsh reminder that not everyone views the events at Balibo through the same viewfinder, the same sense of humanity — and also a clear indication of why we need an IHL regime, some codified means to deliver justice to the victims and their families, and the full weight of the law and punishment to the perpetrators. By seeing war and war reporting only through the prism of Hollywood and Boys' Own comics - an epic struggle of the strong versus the weak, the brave versus the cowards - we create a scenario in which emotionally-charged terms like 'heroes' and 'courage under fire' and 'bravery' and 'winners and losers' give encouragement to the killers, because these are value fields in which fairness, honesty and justice don't play a big role.

As a first move towards wider acceptance of IHL principles, we need to stop viewing and presenting war as an heroic enterprise, and see it for what it fundamentally is - an inhuman, horrific and desperate act by people devoid of imagination, for whom brute force is not the last resort, but usually the first. To that end, we also need not only strong laws to protect journalists who are 
reporting frontline action, but also committed judiciaries and the necessary political will to apply those laws forcefully, and bring to justice those who betray their intent.

\section{References}

Pratt, D. (2009). Getting to know international law. Canadian Red Cross presentation at the Reporting War conference, ABC Ultimo, May 18. Retrieved on 21 January 2010, from www.redcross.ca/article.asp? $\mathrm{id}=12529 \& \mathrm{tid}=001$

Tony Maniaty is a senior lecturer in journalism at the University of Technology, Sydney, a participant at the Reporting War conference in Sydney on 18 May 2009. He is also author of Shooting Balibo, reflecting on the Indonesian invasion of East Timor 1975, the killing of the so-called Balibo Five journalists, and a sixth reporter, Roger East, who investigated the earlier killings. anthony.maniaty@uts.edu.au

\section{TIMARU 2010}

Journalism Education Association of New Zealand Annual Conference, 2 and 3 December Theme:What Editors Want

Partners programme being developed for those who wish to use the conference as the launch for a holiday in the Mainland.

There are flights directly into Timaru from Wellington. Alternatively, fly to Christchurch and drive (two hours).

The JEANZ AGM will be held on 3 December

Convenor: Peter O’Neill Ph: +64 36840845 Email: peter.oneill@aoraki.ac.nz

Abstracts: Jim Tully Ph: +64 3 364288I Email: jim.tully@canterbury.ac.nz

Registration: Janine Burgess Ph: +64 36848240 Email: janine.burgess@aoraki.ac.nz 